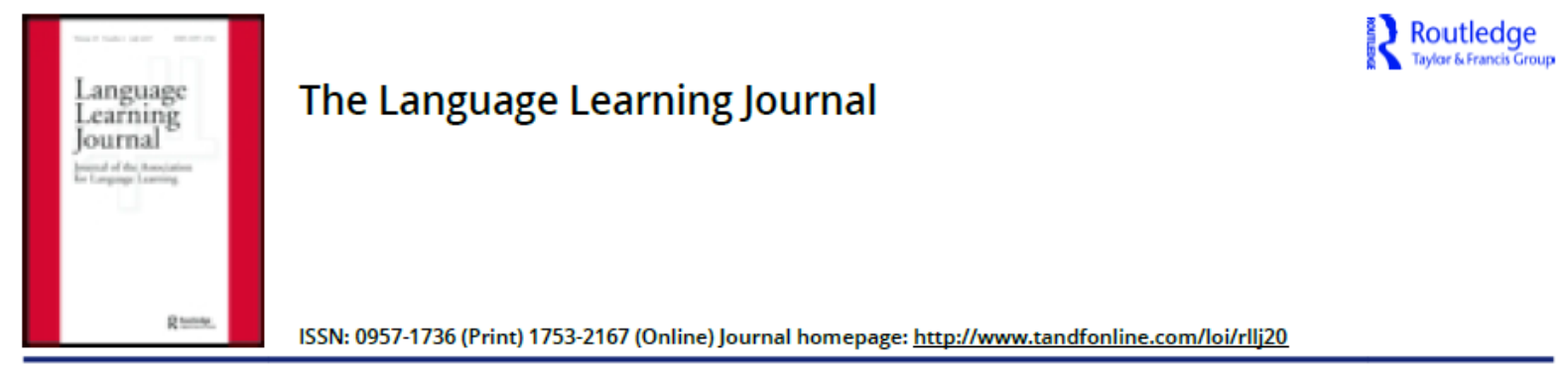

\title{
Teaching linguistics to low-level English language users in a teacher education programme: an action research study
}

\section{Darío Luis Banegas}

To cite this article: Darí Luis Banegas (2017): Teaching linguistics to low-level English language users in a teacher education programme: an action research study, The Language Learning Journal, DOI: $\underline{10.1080 / 09571736.2017 .1370604}$

To link to this article: http://dx.doi.org/10.1080/09571736.2017.1370604

Teaching Linguistics to low-level English language users in a teacher education programme: An action research study

\begin{abstract}
The aim of this study is to investigate the outcomes of teacher educator-initiated action research process at a teacher education institution in southern Argentina. This process was triggered by a challenge which emerged in the 2016 academic year: how to teach a linguistics module through English to low-level English language users in the first year of a programme designed for teaching English as a foreign language at primary and secondary schools in Argentina. Such a situation became a pedagogical opportunity to engage in action research with a group of student-teachers during a whole academic year. Framed in qualitative research, data collection included journals, teaching and learning artifacts, and interviews. Results show that the integration of content and
\end{abstract}


PRE-PUB VERSION

language learning helped student-teachers develop their language proficiency and strengthen their awareness as language users and future teachers.

Key words: Linguistics; proficiency; teacher education; CLIL; action research

\section{Research background}

This study examines the outcomes of a teacher educator-initiated action research process at a teacher education institution in southern Argentina. This process was triggered by a challenge which emerged in the 2016 academic year: how to teach a mandatory linguistics module in English to low-level English language student-teachers in the first year of an initial English language teacher education (IELTE) programme (Author 2014) for teaching English as a foreign language at primary and secondary schools in Argentina. In the paragraphs which follow, three key concepts are problematised: linguistics in teacher education, language proficiency, and CLIL (Content and Language Integrated Learning).

Publications in the field of foreign language teacher education often stress the importance of linguistics, minimally defined as the scientific study of language (McGregor 2015), in teacher development and how teacher educators deal with the challenge of teaching linguistics in IELTE. While it is not within the scope of this study to discuss linguistics, the aim is to problematise how to approach it when linguistics is a mandatory module in language teacher education. In this study, linguistics teaching is approached from a descriptive perspective of language in use in natural settings which allows student-teachers to develop language awareness in the languages they speak and advance knowledge of and about the English language (Arnó-Maciá 2009). Concomitantly, Blanco Gómez and Henderson Osborne (1999: 51) have asserted that in order to 
PRE-PUB VERSION

respond to the challenges of linguistics teaching, 'linguistics cannot be separated from teaching, for a knowledge of linguistics is essential for language awareness in the language teacher.' For example, in an edited volume, Bartels (2005: 406) concludes that 'courses in applied linguistics do seem to have the potential to be successful in changing novice teachers' conceptions about language and language teaching.' Through a descriptive statistics-based study with 61 novice and experienced teachers, LaFond and Dogancay-Aktuna (2009) sought to examine teachers' perspectives on the impact of linguistics knowledge in TESOL (Teaching English to Speakers of Other Languages). Results showed that the novice and more experienced teachers judged the impact of linguistic knowledge in their practices more positively than the teachers with less experience. In a similar vein, Whong (2013) argues that linguistic knowledge can help teachers maximise the implementation of communicative approaches to language teaching as linguistics lends support to understanding the complexities of language learning. In line with Whong, Phipps (2015) notes that modules on, for instance, linguistics or second language acquisition make a profound impact in teachers' trajectories when they are pedagogically approached from a constructivist perspective that encourages reflection, discussion, and links between practice and theory. Such a perspective appears to indicate that student-teachers' linguistics learning should be framed in the same approaches future teachers are expected to follow in their professional practices thus suggesting that linguistics teaching should raise language awareness among student-teachers both as language users and as language teachers.

Johnson (2016: 123) observes that for disciplinary knowledge that includes linguistics to be of relevance to teachers, it must be 'interconnected with the experiential knowledge that teachers bring with them' to language teacher education programmes. This means that a linguistics module should start with teachers' language practices, how they use language and how they think about language and language learning and teaching. Similarly, from a systemic functional linguistics lens, 
PRE-PUB VERSION

Liu and Nelson (2016) suggest that understanding language as a system helps learners, and student-teachers by extension, develop awareness of function and meaning in language teaching and learning. In other words, linguistics may help student-teachers understand their own foreign language learning experiences and from there think about how to teach a language within a communicative approach. Last, in a reflective article on the role of linguistic knowledge in second language classrooms, Correa (2014) stresses that linguistics may help teachers develop their English language proficiency as they develop their language awareness by reflecting on English through English. This situation where the object of study and medium are the same helps teachers discover language rules, apply them in their own identity as language users, and, consequently, improve their proficiency in English.

Thus, it may be agreed that student-teachers benefit from linguistics as a module delivered in English. Nevertheless, the publications reviewed above seem to neglect the proficiency levels student-teachers may need to have to understand and profit from linguistics in IELTE. In foreign language education, proficiency usually refers to the highest level speakers can reach in mastering a language. However, the concept has a broader look and does not imply a level in itself but a range of aspects and applications of a speaker's language practices in a given context. In a concise discussion of the term, Harsch (2017: 250) states that 'proficiency in a second or foreign language comprises the aspects of being able to do something with the language ('knowing how') as well as knowing about it ('knowing what').' In TESOL, proficiency has been under scrutiny not only in relation to learners but also teachers. In a reflective article about the implications of teaching English through English, Richards (2017) asserts that while language proficiency does not necessarily correlate to effective teaching, it does affect teacher's classroom performance and their professional identity and development. In this regard, Freeman (2017) suggests that teachers need to receive language courses which prepare them for teaching, what he calls English 
PRE-PUB VERSION

for teaching. While this option may be envisaged as necessary in short courses and as a temporary solution to teacher scarcity, longer programmes where modules are delivered in English need to offer student-teachers the possibility of expanding their proficiency horizons beyond the limitations of a coursebook or a syllabus. Under this empowering view of language improvement in teacher education programmes, student-teachers may further profit from linguistic knowledge provided that their proficiency in English is such that they can access the contents with confidence. This may entail that future teachers develop their English language skills to higher levels. Richards (2015: 113) reminds us that teachers' foreign/second language proficiency 'does affect how well a teacher can teach a second language.' He adds that

teachers with limited English proficiency may tend to overuse the students' mother tongue in teaching, may be unable to provide suitable language input for learning and may become over-dependent upon the textbook and audio player (2015: 113).

Therefore, IELTE programmes should offer symbiotic opportunities through which language development and content knowledge are enhanced. One opportunity to merge these two dimensions of teaching may be present in CLIL, which could be defined as an educational approach through which content (in the case of initial teacher education, linguistics, literature, phonetics, syntax, specific didactics) is delivered through a language, in the context of this study English, other than learners' L1 (Ball, 2016). CLIL pedagogies suggest that sources of input (e.g. written text) and activities could be modified and sequenced according to language and cognitive demands (Doyle et al. 2010; Moore and Lorenzo, 2015). Based on current studies of applied linguistics on CLIL (Llinares and Morton 2017), the aim of CLIL is dual: to help learners improve their language proficiency and confidence in the target language and learn subject matter (Goris, 
PRE-PUB VERSION

Denessen and Verhoeven 2017; Lasagabaster and Doitz 2016). While these aims and CLIL practices are usually found in primary, secondary, and higher education across contexts (Ball et al. 2015;

Devos 2016; Llinares and Morton 2017; Yang 2016), they can be transferred to IELTE in settings where English is the language of instruction as student-teachers are still developing their English language proficiency together with knowledge of/about language and knowledge of professional practice. Despite this possible transference, little has been published concerning how content and language learning are integrated in IELTE programmes which recently also offer CLIL as an approach to be implemented in primary and secondary schools. In IELTE, teacher educators may need to scaffold both content and language so that student-teachers can benefit from modules content- and language-wise. As a response to this niche in the literature, this study is located at the intersection of language proficiency, CLIL, and linguistic knowledge.

\section{Context}

The experience took place at a tertiary institution in southern Argentina. For the four-year IELTE programme under examination, potential student-teachers are only required to hold a secondary school certificate, and there is no mandatory entry level regarding their English language proficiency. The IELTE programme included several mandatory English-medium modules throughout the four years. According to Author (2014), teacher educators in charge of these modules were encouraged to base their practices on current sociocultural perspectives (Lantolf and Poehner 2014; Swain et al. 2015) and CLIL as an approach to promote, in this case, subjectspecific content learning together with English language development among student teachers.

According to the curriculum and in line with CLIL objectives, the main aim of the Introduction to Linguistics module was two-fold: (1) to help learners improve their English 
PRE-PUB VERSION

language proficiency, and (2) to help them make informed decisions in their teaching practices by resorting to linguistic knowledge. Drawing on Cots and Arno's (2005) terms, the programme sought to develop future language teachers as language analysts within a pedagogical working framework.

Introduction to Linguistics was a two-term module which started in March and finished in November. The cohort of Year 1 student-teachers who participated in this study had an 80-minute lesson once a week which represented 31 lessons organised in three units during the course of the academic year. The core contents were:

- Unit 1. Definitions of language. Signs. Features of human language.

- Unit 2. Linguistics: definitions, history, and scope. Key figures in Linguistics development (eg. Saussure, Chomsky, and Halliday). Synchronic and diachronic linguistics. IndoEuropean languages. Brief history of English.

- Unit 3. Language as a system. Microlinguistics: phonetics and phonology, morphology and syntax, semantics and pragmatics. Macrolinguistics: systemic functional linguistics, corpus linguistics, applied linguistics, psycholinguistics, sociolinguistics, forensic linguistics, stylistics, and discourse analysis.

In Year 1, the 2016 cohort consisted of twelve student-teachers. In March they were administered an English-language entry exam to collect information about their level of English. They were tested on grammar, reading comprehension, and speaking. According to CEFR (Common European Framework of Reference for Languages) standards, they were A2-B1 English language users. This proficiency level was regarded as limited given the fact that student-teachers were expected to complete modules delivered in English. 
PRE-PUB VERSION

Against such a theoretical background and context, the following questions guided this study:

- How can linguistics be taught effectively in English to student-teachers with limited English proficiency?

- Does a focus on content help student-teachers become higher level English language users?

\section{Methodology}

Action research (AR) was assessed as the most convenient research method. Roberts (1998: 41) reminds that that to Kurt Lewin, the father of action research, the first element of action research is 'a problem of real meaning to all participants'. For the purposes of this investigation, AR was conceived as a research approach conducted by teachers, in this case a teacher educator and author of this article, to investigate their own educational practices for transformation and empowerment through action. AR has been the core of recent publications in teacher education (Amez 2015; Crawford-Garrett et al. 2015; Edwards and Burns 2016; Güngör 2016; Ulvik and Riese 2016, Villacañas de Castro 2015, 2016) and it hoped to become a salient feature across IELTE endeavours with the aim of promoting teacher-educators' research (Author 2017).

Drawing on Burns (2010), the investigation was organised in three AR cycles. Each cycle coincided in time with the three syllabus units found in Introduction to Linguistics, and in terms of stages they included: issue identification, acting, intervening, and evaluating. An ecological perspective (Arcidiacono, Procentese and Di Napoli 2009; Pinnow 2012) was considered to enact this AR project, i.e., the research procedures aimed at the participants' direct benefit and emerged from the usual teaching and learning processes and did not represent intrusive or uncommon 
PRE-PUB VERSION

practices at the institution. However, the student-teachers were informed of the research and potential publication of findings.

AR cycles included the instruments described below with two aims: (1) to promote reflection on action among the teacher educator and the student-teachers (Schön 1983) and (2) to triangulate data to enhance credibility (Bartels 2005; Brown 2014). Ethical procedures such as anonymity and confidentiality were in place during the research process.

- Student-teacher journal: during the whole academic year the participants were asked to answer the following questions at the end of each lesson: What did I learn today and how? Do I feel I'm developing as a future teacher? Do I feel I improve as a language user? It was agreed that they could keep their journal in either Spanish and/or English and that their entries would be summarised before group interviews.

- Teacher educator journal: during the whole academic year I kept a journal with a summary of the lessons and perceptions after each lesson.

- Group interviews: at the end of each of the three units in the syllabus, one interview with the 12 student-teachers was conducted to gather their entry-driven perspectives. I also shared my own recorded thoughts with them. Spanish-medium interviews took place in May, September and November 2016. Interviews were audio-recorded and orthographically transcribed.

- Student-teachers' artifacts: copies of their mid-term exams were collected to analyse those exam questions which asked them to produce elaborated answers. Exams were administered in June and November 2016.

- Teaching artifacts: for each unit in the syllabus I developed a collection of worksheets and reading materials. 
PRE-PUB VERSION

Inscribed in qualitative research (Holliday 2016; Richards 2003), data analysis was examined

through open-ended inductive coding and thematic analysis of emerging categories (Saldaña

2016), hence unifying themes. Once these unifying themes were established and illustrated with

data extracts to form a codebook, data collected was analysed a second time (DeCuir-Gunby,

Marshall and McCulloch 2011). Unifying themes were first organised according to perspectives

(Table 1) and then reorganised in thematic networks (see Discussion). A colleague acted as a

second data analyst using the codes and unifying themes established. Differences in coding and

categorisation led to discussion of data extracts for reliability purposes. Furthermore, teaching

artifacts and student-teachers' mid-term exams were examined through content analysis

(Silverman 2010).

Table 1. Unifying themes

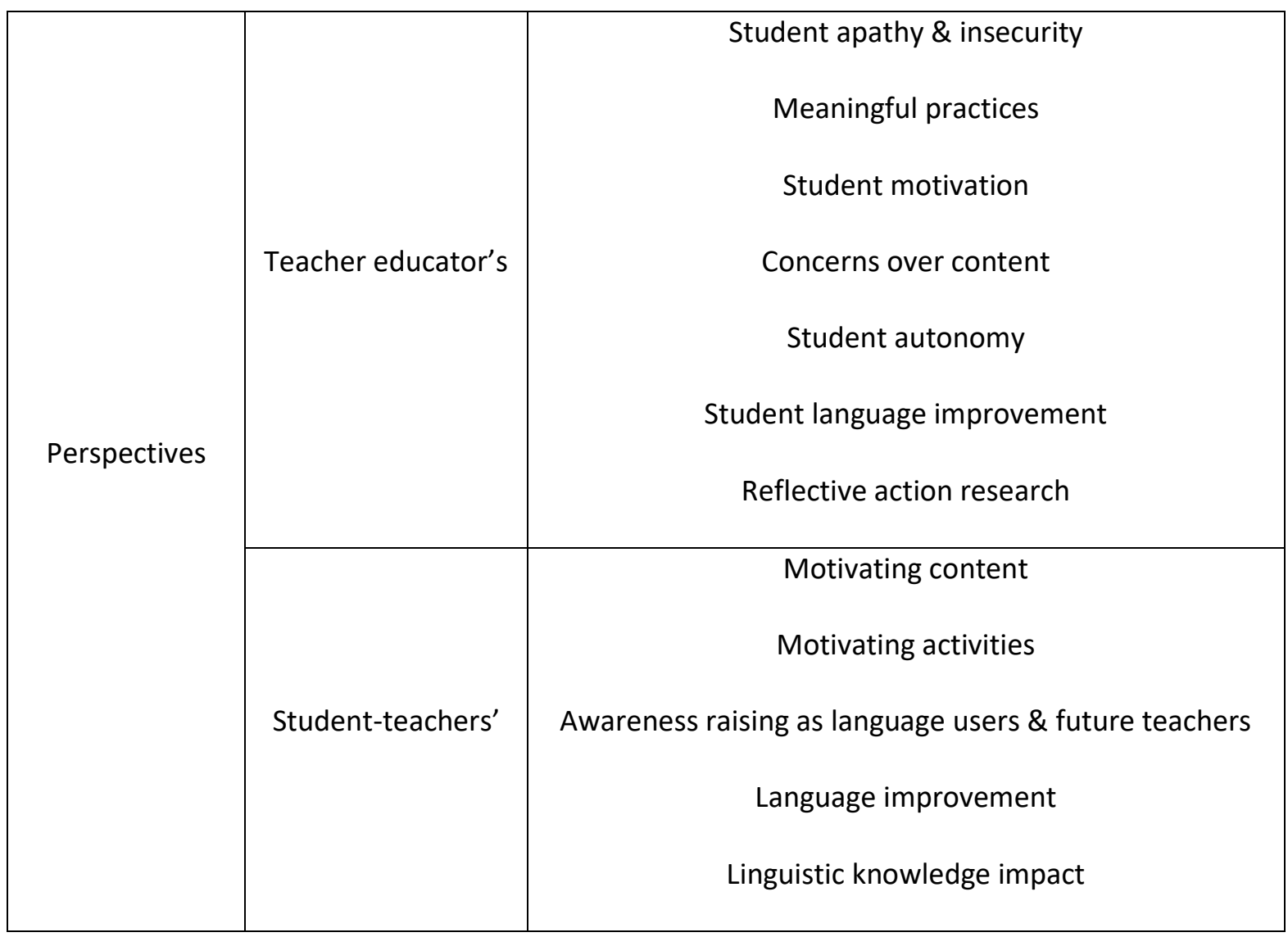


PRE-PUB VERSION

This following sections present the results obtained through the teacher educator journal, group interviews, student-teachers' exams and teaching materials. Results are presented chronologically under each action research cycle as each cycle and syllabus unit shaped the progress of the module thus showing the 'natural history' (Silverman 2010: 316) of the project. In the Discussion section data is problematised under each of the guiding research questions.

\section{Cycle 1 (March-May 2016)}

\section{Teacher educator journal}

In total the journal contained 31 entries. I wrote the entries either at end of each lesson at the institution or the following day at home. In Cycle 1 there were 11 entries. Through thematic analysis three unifying themes emerged: (1) students' apathy, (2) students' insecurity, and (3) meaningful practices.

The category students' apathy condenses those codes which reflected the perceptions of disengagement or demotivation with the content and overall programme. Excerpt 1 (E1) illustrates this category:

I feel a distance between them and the module. They don't participate at all. They have no questions. (29.03.16) (E1) 
PRE-PUB VERSION

During the first half of Cycle1, students' insecurity emerged as a recurrent theme. Almost every entry contained traces of student-teachers' being perceived as unsure of what was expected from them. They needed the tutor's constant approval to complete an activity:

The group activity with cardboard paper and cotton to work on the creational aspect of language was a disaster. They didn't know what to do. Like they couldn't think outside the box. (22.03.16) (E2)

The last theme, meaningful practices, became a confluence of codes around teaching concerns with teaching strategies and practices:

How can I prepare lessons that are meaningful? Perhaps I can change to focus and contents to make the topics more attractive and engaging? (12.04.16) (E3)

In this case, entries were structured as rhetorical questions which signalled my concerns over how to attract the students and narrow the distance between linguistics and everyday life. Entries also described teaching practices which included: elicitation of student-teachers' prior knowledge and examples from Spanish, use of Spanish to draw comparisons between languages, PowerPoint-supported lessons, group work, and a combination of teacher-educator- and studentcentred stages in the lesson. These were repeated throughout the three action research cycles.

\section{Teaching artifacts}


PRE-PUB VERSION

The teaching artifacts referred to the worksheets developed for Unit 1 in the syllabus. For this unit of work, input materials came from:

- Widdowson, H. G. (1996). Linguistics. Oxford: Oxford University Press.

- McGregor, W.B. (2015). Linguistics: An introduction (2nd. Edition). London/New York: Bloomsbury.

- Linguistics Society of America's pamphlets about linguistics in everyday life.

The unit featured activities which involved matching (TA 1), rearranging definitions, completing tables, gap-filling, or answering questions.

1. We have said that signs could be iconic or symbolic. Which statements refer to "icons" and which to "symbols"?

a. In this type of sign the form has no apparent similarity to the meaning.

b. It's a sign that has a form resembling its meaning in some way.

c. It's a sign where the form and meaning are related purely by convention.

d. Its form is never an exact representation of the meaning; it shows salient features in stylized ways.

e. The form shows some characteristics of the corresponding concept.

In terms of cognitive and language in use skills, activities promoted understanding and identifying. The student-teachers were asked to produce limited or controlled responses. 


\section{Group interview}

This first group interview yielded the following unifying themes: (1) motivating content, (2) raising awareness, (3) motivating activities, (4) language improvement, and (5) uncertainty about impact in professional development.

As regards motivating content, all the student-teachers underlined that they had experienced a sense of wonder and motivation as they 'discovered' a new science:

I like all the terms and definitions we've learnt. It's like I can talk about language now. (Judith) (E4)

With reference to raising awareness, 11 student-teachers explained that their entries were about how each topic helped them think about how they had learnt a language. They agreed that the contents increased their metalinguistic reflection.

It's amazing how I've started thinking about how we speak Spanish or English. I am more aware of how languages work and how we can study them. (Ana) (E5)

The following activities became motivating as they helped them focus on content and could be completed without peer or teacher support: completing tables, identifying theories, video-based activities, true/false statements, gap-filling, matching terms and definitions. In contrast, activities such as reading a text and answering questions or re-ordering a text (jumbled paragraphs) proved less engaging. 
PRE-PUB VERSION

All the student-teachers expressed the perception that they had improved their English proficiency. They all remarked that they had developed their reading skills given the engaging nature of the texts and activities. Similarly, acquiring subject-specific terminology was assessed as an asset. However, they felt that they would have liked to have further opportunities for oral skills development.

Last, uncertainty about impact in professional development was clear in Cycle 1. Except for one student-teacher who expressed that she now believed she was in a position to answer students' questions about the language, the rest could not see the link between linguistic knowledge and professional practice.

I think it's important for me to know about language but I can't see how it can help me as a teacher. I always left that question unanswered in my journal. (Victoria) (E6)

\section{Cycle 2 (May - August 2016)}

\section{Teacher-educator journal}

In Cycle 2, the journal contained ten entries. Unifying themes are illustrated below.

From a focus on demotivation in Cycle 2 (apathy), there appeared signs of interest among the student teachers, therefore students' motivation was common in the journal entries:

Saussure's theory of signs attracted them a lot! They started discussing how to categorise different signs. Issues around arbitrariness and cultural transmission also helped them take charge of the lesson. They did all the talking! Lots of language mistakes to work on, but they got interested in the content (07.06.16) (E7) 
PRE-PUB VERSION

A new category emerged in the process, concerns over content:

I need to make sure I don't offer too little. I don't want to feel like I'm teaching secondary school students. But I don't want to give them too much to digest, this is an Intro only, then they'll do SFG [Systemic Functional Grammar] or DA [Discourse Analysis] (31.05.16)

As a tutor I noticed that the student teachers seemed motivated to learn. Yet, I did not wish to compromise academic rigor and quality over motivation.

\section{Teaching artifacts}

In Unit 2, the input material came from the reading sources included in Unit 1 and videos from YouTube which summarised the history of English, or evolution of Indo-European languages. Accordingly, activities included correcting statements (TA2), answering questions, completing sentences, or completing graphic organisers.

\section{Watch the video "How did English evolve?" Are these statements true or false? Correct the false ones.}

a. The words we use to describe a situation reveal the context of such a situation.

b. In 400 CE the Celts were ruled by Romans.

c. The Celts protected the Romans from the Saxon tribes of Northern Europe.

d. When the Roman Empire collapsed, the Romans left Britain.

e. The Angles, Saxons, Jutes and Fresians integrated with the Celts to form kingdoms in the British Isles. 
f. While these tribes were on the isles, middle English was the common language.

g. Anglo-Saxon was a Germanic language.

h. In the 1500 Vikings started to invade the isles.

\section{Student-teachers' artifacts (mid-term exams)}

The first mid-term exam was administered in June 2016 and it included contents covered in Units 1 and 2 of the syllabus. The exam consisted of four activities. While the first three required student-teachers to produce little language, the last activity (TA3) asked them to offer elaborated answers.

\section{Answer ONE of the following questions (3p):}

a. What's the difference between synchronic and diachronic linguistics?

b. Is it easy to locate the origin of language in time and space? Explain.

c. Do only grammar and vocabulary change in a language over time? Explain.

d. Does language change mean language improvement? Explain.

Students' answers tended to be between 4-6 lines long in a semi-formal register (Student Artifact 1). Language mistakes occurred at the level of clause structure and word choice. 


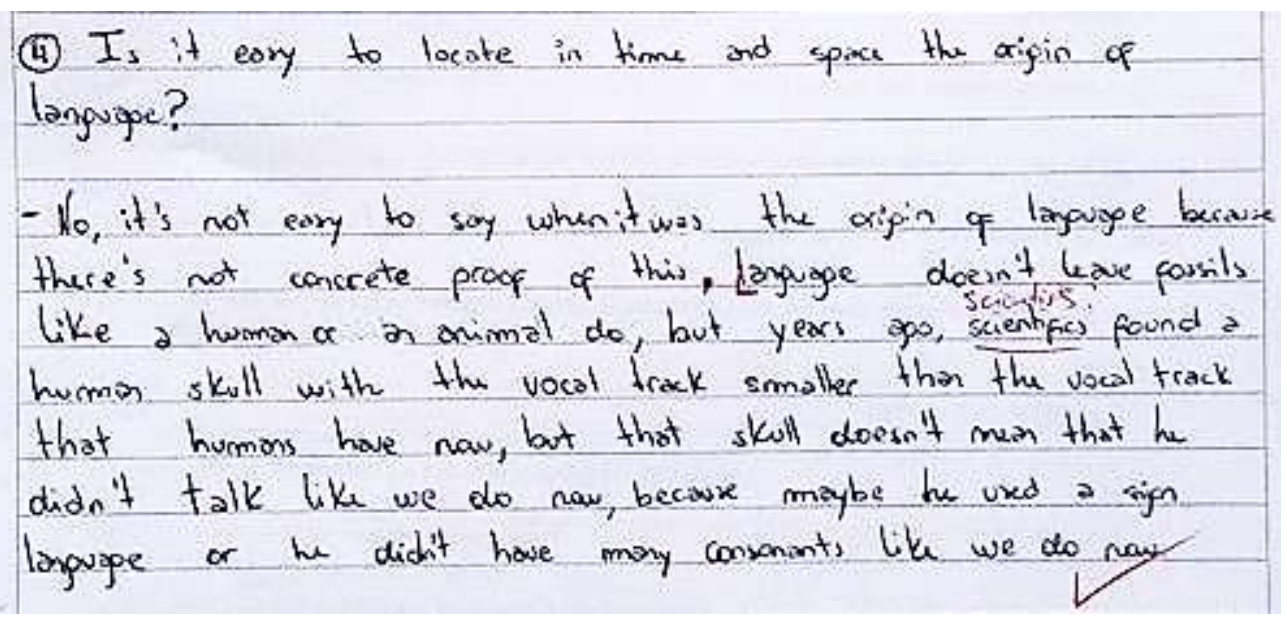

(SA1)

\section{Group interview}

The second group interview yielded the following unifying themes: (1) language teaching awareness, (2) motivating contents, and (3) motivating activities.

All the student-teachers referred to the opportunities to reflect on language together with teaching and learning:

I think I've now developed awareness about how prescriptive our teaching can be, and perhaps we just need to be more descriptive about how people speak. (Florencia) (E9)

The second and third categories were similar as they referred to motivation. However, the student-teachers drew the distinction between contents and activities. Only three expressed their motivation with both contents and activities. The following excerpts illustrate these two categories: 
PRE-PUB VERSION

I found it fascinating to learn about the scope and branches of Linguistics. The difference between formalism and structuralism, evolution of Linguistics, the focus on meaning and function today. (Agustina) (E10)

And the activities. The timeline was really helpful to organize the development of Linguistics. Even the oral quizzes. Those weekly questions help me study every week. It's good for remembering and understanding. (Judith) (E11)

This last excerpt reveals student-teachers' connections between activities and cognitive skills which may also reveal their awareness of their own progress as learners.

Cycle 3 (September - November 2016)

\section{Teacher-educator journal}

Based on the ten entries I wrote during this last action research cycle, the following running themes were identified (1) student's improvement (E12), (2) teacher autonomy (E13), (3) reflective action research (E14), and (4) reading materials (E15):

I see they're more willing to speak. The presentations they gave on different Ling branches as a wrap-up were wonderful. Very few language mistakes. Clear content. (08.11.16) (E12)

Today's lesson showed me that I rather produce my own materials than choose a resource book from the market. I now feel more confident to produce materials based on my students. (27.09.16) (E13) 
PRE-PUB VERSION

AR I love you! AR allows me to me systemic re reflection and act, and investigate to produce direct and tangible impact on the students and myself! (25.10.16) (E14)

Widdowson, thank you very much, but we won't see you again in 2017. Longer texts will be more beneficial. You're too much condensed. (15.11.16) (E15)

\section{Teaching artifacts}

Together with input from the books mentioned in Cycle 1, Unit 3 in the syllabus featured systemic work with videos, reading texts, graphic organisers, cartoons for analysis and news items. The work on different branches of Linguistics allowed me to work with different resources and assignments for student-teachers to submit. In addition, this unit included student-teachers' group presentations on branches of Linguistics, e.g. Forensic Linguistics.

Activities promoted further language development. The following activity (TA4) illustrates higher levels of cognitive engagement and language demand.

Choose ONE of these articles to read:

a. http://news.bbc.co.uk/2/hi/science/nature/7600769.stm

b. https://www.washingtonpost.com/lifestyle/magazine/should-texts-e-mail-tweetsand-facebook-posts-the-be-new-fingerprints-in-court/2015/02/19/a5ec2bf6-6f3211e4-8808-afaa1e3a33ef story.html

c. http://www.cbc.ca/news/politics/trudeau-obama-ottawa-meeing-macdonald$\underline{1.3658538}$ 
d. http://www.ctvnews.ca/health/bilingual-children-better-at-problem-solving-study$\underline{1.2767495}$

e. http://www.forbes.com/sites/ryanholiday/2012/07/16/what-is-media-manipulationa-definition-and-explanation/\#1624fc323fc6

f. http://www.naturalnews.com/036824 Presidential election politicians manipulation $\underline{. h \mathrm{tml}}$

g. http://www.telegraph.co.uk/news/celebritynews/10174136/BBC-wont-employ-poshvoices-any-more-says-Charlotte-Green.html

h. http://www.bbc.com/news/technology-10971949

Based on the article of your choice, answer these questions

a. What article did you choose? What made you choose it?

b. What's the article about?

c. What branch(es) of Linguistics can be related to the article? Support your answer.

\section{Student-teacher artifacts (second mid-term exam)}

In November, student-teachers completed a second mid-term exam based on contents from units 2 and 3 in the syllabus which included two gap-filling activities and an open task (TA5)

Choose TWO of the following questions and develop them as fully as possible.

a. Are polysemy and homophony the same? 
b. What does communicative competence involve?

c. What does Grice's cooperative principle involve?

d. What kinds of morphemes can we find in English?

e. What semantic relations can we find among words?

f. What's the difference between Semantics and Pragmatics?

g. According to the texts we read, what's the scope of Linguistics?

Student-teachers' answers were between 10-12 lines long. They included subject-specific terminology and clearly constructed paragraphs. There were language mistakes at the level of syntax such as overuse of the definite article, possibly due to Spanish interference. The following answer (SA2) is representative of the group's performance:

\section{(d) We can find two kinds of norphemes, the} inflectional morphemes aud the derivational morghemes. - The inflectional morphemes are called allomorphs, are the ones that dou't chanfe the meduing of the word or the frammatical cathefory. for example the verb "play", if I add ed chaufes to past but it is still a verb, if I add ' $s$ ', is pural, but it's still a verb

- The derivationas morphemes, on the other haud, chaufe both thinfs, the prammatical cattegfory and the meaning. for example if I add a - w to the word success, it changes from a noun to an adjective

this morphemes are called affixes (prepixes and siffies) 
PRE-PUB VERSION

\section{Group interview}

This last group interview allowed the student-teachers to assess not only this last cycle but also the whole subject and their development based on their journals. The following unifying themes emerged: (1) language improvement, and (2) linguistic knowledge impact in future teaching practices.

As regards language improvement, all the student-teachers coincided that the subject had equipped them with language tools:

We learnt a lot of vocabulary and pronunciation because of the videos and the texts we read. But Widdowson was hard to follow. (Mauricio) (E16)

In addition, four student-teachers indicated that focusing on content, their attention to language increased. For instance, a student-teacher explained:

As I paid more attention to what we were learning, I also paid more attention to language because I wanted to be clear and respect what we had studied. Like, when we had to make our presentation on Sociolinguistics, I looked the words up and checked the pronunciation. In our group we did a bit of rehearsing and recorded ourselves to spot mistakes or other problems. Like when you are interested in what you talk about, then language comes out better. (Florencia) (E17) 
PRE-PUB VERSION

With reference to the perceived impact of linguistic knowledge in their teaching practices, unlike Cycle 1, they began to reflect on the kind of background Linguistics could provide them with to address different issues:

I think Linguistics will help us answer students' questions like: Is American English a deformation of British English? Why are there in English similar words to Spanish? Is it accurate to say that some people speak better than others? (Catarina) (E18)

\section{Discussion}

First, this section problematises the data gathered following the research questions which guided this study. Second, the emerging unifying themes are discussed around thematic networks under the light of the theoretical background.

\section{Effective linguistics teaching}

The focus of the first research question was how to teaching Linguistics in English to student-teachers with limited English proficiency. As the academic year and research cycles unfolded, linguistics content was scaffolded by breaking it down into manageable parts such as definitions or addressing one topic per lesson. While the main concerns regarding content complexity derived from the teacher-educator's logical responsibility with ensuring programme quality (E8), the student-teachers approached linguistics with a sense of wonder and interest (E4, E10). 
PRE-PUB VERSION

Topics were presented through materials which moved from general to specific content and vocabulary, which meant that subject-specific terminology was constructed on general academic vocabulary. In terms of length and multimodality, texts increased as months progressed and they included videos and online resources which student-teachers could access outside the classroom. It should be highlighted that reading texts included authentic materials, for example chapters from McGregor (2009) and Yule (2017), accompanied by comprehension questions, together with modified texts to respond to student-teachers' proficiency. Text modification included simplification or extension by means of examples, paraphrasis, and illustrations. Modifications also included enhancing textual cohesion through noun repetition, insertion of synonyms, or fewer anaphoric or cataphoric references. Through these texts, student-teachers concentrated on remembering and understanding new concepts through activities with lowlinguistic demand (e.g. matching, gap filing, or rearranging items, or identifying true/false sentences as shown in TA2) which are usually found in ELT practices. Graphic organisers (E11) and videos played a major role in consolidating and reviewing content throughout the academic year. On the other hand, activities which required a higher linguistic demand (e.g. TA3-TA5) often included an element of choice so that student-teachers could work on what they felt more confident.

In general, content and language scaffolding was achieved by implementing CLIL practices as regards lesson preparation and materials development (see Ball et al. 2015; Moore and Lorenzo 2015).

Impact of content in language development 
PRE-PUB VERSION

The second research question sought to examine whether concentrating on content

teaching increased student-teachers' language proficiency. From Cycle 1 the student-teachers

perceived an increase in their subject-specific and general academic vocabulary. They also

perceived language skills development from reading skills to oral skills and pronunciation

particularly by the end of the academic year (E17). A common feature across the experience was

their awareness-raising development about language and how languages work.

Student-teachers' perceptions were confirmed through the elaborated answers included

in the mid-term exams. Student-teachers' texts showed development in paragraph build and use

of specific terminology. They also constructed answers based on more than one reading text and

moved from descriptive summary-like texts to analytical pieces. Nevertheless, mistakes at the

level of subject-verb agreement, order of clause constituents (e.g. verb + direct object + adverbial

phrase), and spelling remained (SA2). This could be assessed as a sign of content-driven language

development, ie, the student-teachers could produce complex answers because of the motivation generated by the content they wished to write about (E17).

\section{Perceptions and practices}

While the sections above address the research questions which guided this study, the data

and unifying themes reveal other related aspects which call for further examination under more

complex thematic networks (Figure 1). Such an examination shows key considerations teacher

educators may wish to include when they teach linguistics in IELTE.

Figure 1. Unifying themes revisited 


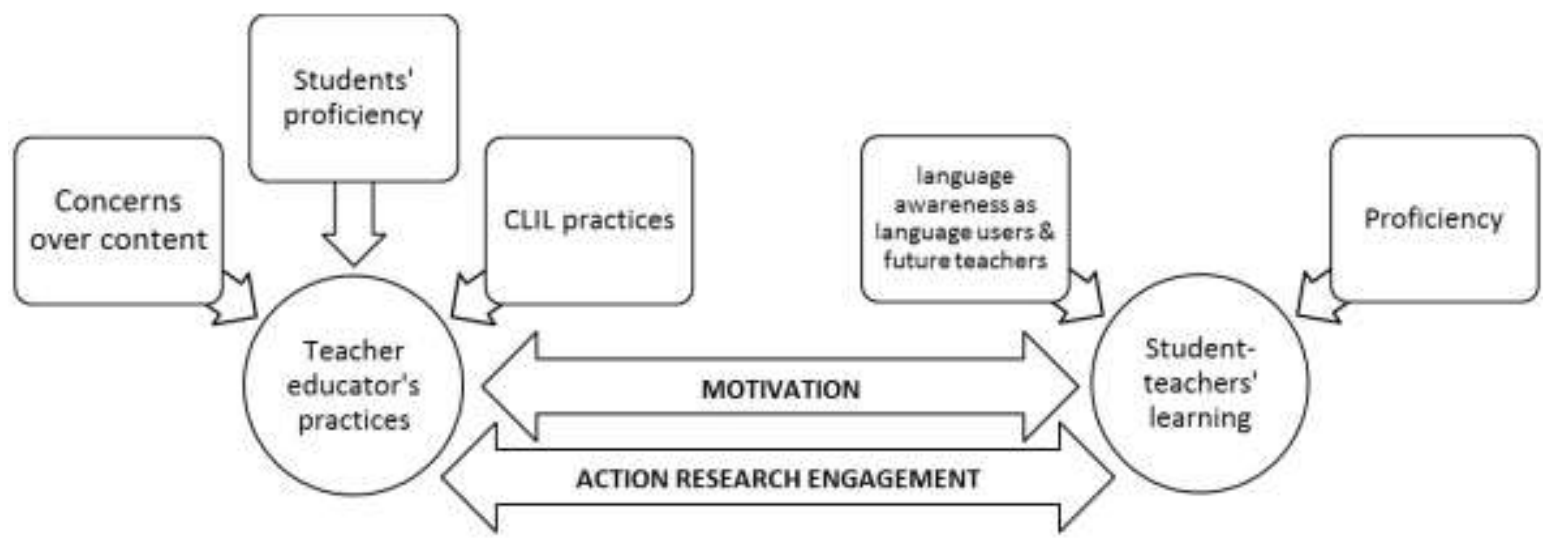

My teacher educator's practices were transformed by my motivation and that of my

student-teachers to learn Linguistics effectively. It was through action research engagement (E14)

that such transformation and synergy were achieved as action research instruments and

motivation acted as cohesive forces. For example, the teacher-educator journal reveals that my

perceptions as a tutor became more positive and wide-ranging as there was a fluctuation from a

focus on my concerns over content, student-teachers' apathy or insecurity (E1) to their motivation

and language proficiency (E3, E12). Driven by this shift in focus, my practices shifted towards CLIL

as this approach provided me with the strategies to help students learn both content and

language within a motivating environment. CLIL practices included (1) materials development

which responded to student-teachers' prior knowledge, and (2) their systematic evaluation

through action research as the cycles described above show. In particular, materials development included activities which moved from understanding (TA1) in Cycle 1 to analysing and evaluation (TA4) in Cycle 3. As the research cycles and contents unfolded, complexity was increased through the provision of longer texts and video-based activities (TA2) which student-teachers could complete at their own pace outside the classroom. This development signals that negotiation can be explored even at higher education level. In this regard, procedural negotiation (Breen and 
PRE-PUB VERSION

Littlejohn 2000) was achieved through the incorporation of student-teachers' interests and the inclusion of choice in written tasks (TA5). While this last procedure is not original in higher education, it allows less proficient student-teachers focus on one specific aspect of subject-matter knowledge they perceive they can elaborate on with linguistic confidence.

Similarly, student-teachers' learning was transformed by their motivation and action research engagement as they observed progress in content learning and development in their language proficiency. CLIL proved to be an effective approach to implement in teaching Linguistics in IELTE. Scaffolding content learning created dynamic spaces for developing student-teachers' language awareness at two interrelated identities: language awareness as language users (E5, E17) and language awareness as future teachers (E9, E18). My perceptions of student-teachers' proficiency and their own awareness of their proficiency became aligned through CLIL practices informed by AR carried out during a whole academic year.

\section{Conclusion}

While this is a small-scale study configured by the specificity of the context in which it took place, the outcomes could resonate with foreign language teacher education programmes in other settings. The lessons learned in this experience could be summarised under three interdependent dimensions: motivation, AR, and CLIL in IELTE.

Teacher motivation and student motivation in synergy are driving forces which should not be overlooked in higher education. Listening to our own voices and interests can lead IELTE actors to embrace AR with the aim of identifying, understanding, acting, and reflecting on professional practices. Through AR, teacher educators can exercise their autonomy and adopt CLIL as an 
PRE-PUB VERSION

approach which may help student-teachers understand the complexities, challenges, and

affordances of learning (through) a foreign language even at IELTE level. Through these three

dimensions, student-teachers may experience pedagogies themselves and therefore they may be

better equipped should they need to implement similar pedagogies with their learners. Similarly,

they engage in AR with their teacher educators, and thus, action research is not only read about,

but it is enacted in their own trajectories through their own agency and co-participation for their

professional development not only as English language users but also as future teachers.

While this study suggests that teaching linguistics may help shape student-teachers'

trajectories in IELTE at content learning and language proficiency levels, future research is needed

to investigate the extent to which course-based linguistic knowledge informs teachers' practices

when they, for example, provide feedback to learners, or introduce a new language item in their

lessons.

\section{References}

Amez, M. 2015. Desire to end violence: human rights and intercultural citizenship in teacher education. Argentinian Journal of Applied Linguistics 3, no. 2: 104-24.

Arcidiacono, C., F. Procentese and I. Di Napoli. 2009. Qualitative and quantitative research: an ecological approach. International Journal of Multiple Research Approaches 3, no. 2: 163-76. DOI: 10.5172/mra.3.2.163

Arnó-Maciá, E. 2009. Knowledge about language in English language courses for future language professionals. Nordic Journal of English Studies 8, no. 1: 5-39.

Author 2014 
PRE-PUB VERSION

Author 2017

Ball, P. 2016. Using language(s) to develop subject competences in CLIL-based practice. Pulso 39, 15-34.

Ball, P., K. Kelly and J. Clegg. 2015. Putting CLIL into Practice. Oxford: Oxford University Press.

Bartels, N. 2005. Applied linguistics and language teacher education: what we know. In Applied Linguistics and Language Teacher Education, ed. N. Bartels, 387-404. New York: Springer.

Blanco Gómez, L. and R. Henderson Osborne. 1999. Linguistics and language teaching: friends or foes? Encuentro. Revista de Investigación e Innovación en la clase de idiomas 2: 50-7.

Breen, M. P. and A. Littlejohn, eds. 2000. Classroom Decision-Making: Negotiation and Process Syllabus in Practice. Cambridge: Cambridge University Press.

Brown, J. D. 2014. Mixed Methods Research for TESOL. Edinburgh: Edinburgh University Press.

Burns, A. 2010. Doing Action Research in English Language Teaching: A Guide for Practitioners. New York/Abingdon: Routledge.

Correa, M. 2014. Teaching (theoretical) linguistics in the second language classroom: Beyond language improvement. Porta Linguarum 22: 161-71.

Cots, J. M. and E. Arnó. 2005. Integrating language teachers' discipline knowledge in a language course. In Applied Linguistics and Language Teacher Education, ed. N. Bartels, 59-78. New York: Springer. 
PRE-PUB VERSION

Crawford-Garrett, K., S. Anderson, A. Grayson and C. Suter. 2015. Transformational practice: critical teacher research in pre-service teacher education. Educational Action Research 23, no. 4: 479-96. DOI: 10.1080/09650792.2015.1019902

DeCuir-Gunby, J. T., P. L. Marshall and A. W. McCulloch. 2011. Developing and using a codebook for the analysis of the interview data: an example from a professional development research project. Field Methods 23, no. 2: 136-55. DOI: 10.1177/1525822X10388468

Devos, N.J. 2016. Development of CLIL into diverse contexts. Educational Linguistics 24, 11-36. DOI: 10.1007/978-3-319-22219-6_2

Doyle, C., P. Marsh and P. Hood. 2010. Content and Language Integrated Learning. Cambridge: Cambridge University Press.

Edwards, E. and A. Burns. 2016. Language teacher action research: achieving sustainability. ELT Journal 70, no. 1: 6-15. DOI: 10.1093/elt/ccv060

Freeman, D. 2017. The case for teachers' classroom English proficiency. RELC Journal 48, no. 1: 3152. DOI: $10.1177 / 0033688217691073$

Goris, J., E. Denessen and L. Verhoeven. 2017. The contribution of CLIL to leaerners' international orientation and EFL confidence. Language Learning Journal, DOI:

$10.1080 / 09571736.2016 .1275034$

Güngör, M. N. 2016. Turkish pre-service teachers' reflective practices in teaching English to young learners. Australian Journal of Teacher Education 41, no. 2: 137-51.

Harsch, C. 2017. Proficiency. ELT Journal 71, no. 2: 250-53. DOI: 10.1093/elt/ccw067

Holliday, A. 2016. Doing and Writing Qualitative Research, 3rd ed., London: Sage. 
PRE-PUB VERSION

Johnson, K. E. 2016. Language teacher education. In The Routledge Handbook of English Language

Teaching, ed. G. Hall, 121-37. Abingdon/New York: Routledge.

LaFond, L. and S. Dogancay-Aktuna. 2009. Teacher perspectives on linguistics in TESOL teacher education. Language Awareness 18, no. 3-4: 345-65. DOI: 10.1080/09658410903197348

Lantolf, J. P. and M. E. Poehner. 2014. Sociocultural Theory and the Pedagogical Imperative in L2 Education: Vygotskian Praxis and the Research/Practice Divide. London/New York: Routledge.

Lasagabaster, D. and A. Doiz. 2016. CLIL students' perceptions of their language learning process: delving into self-perceived improvement and instructional preferences. Language Awareness 25, no. 1-2: 110-26. DOI: 10.1080/09658416.2015.1122019

Liu, D. and R. Nelson. 2016. Teaching language as a system. In The Routledge Handbook of English Language Teaching, ed. G. Hall, 413-27. Abingdon/New York: Routledge.

Llinares, A. and T. Morton, eds. 2017. Applied Linguistics Perspectives on CLIL. Amsterdam/ Philadelphia: John Benjamins.

McGregor, W. (2009). Linguistics: An Introduction. London/New York: Continuum.

Moore, P. and F. Lorenzo. 2015. Task-based learning and content and language integrated learning materials design: process and product. Language Learning Journal 43, no. 3: 334-57. DOI:

$10.1080 / 09571736.2015 .1053282$

Phipps, S. 2015. Constructivist language teacher education: An example from Turkey. In International Perspectives on English Language Teacher Education: Innovations from the Field, ed. T. S.C. Farrell, 16-35. Basingstoke: Palgrave Macmillan. 
PRE-PUB VERSION

Potocka, D. 2011. Second language teacher education: shifting paradigms and future challenges. In Extending the Boundaries of Research on Second Language Learning and Teaching, ed. M.

Pawlak, 169-79. Berlin Heidelberg.

Richards, J.C. 2017. Teaching English through English: proficiency, pedagogy and performance.

RELC Journal 48, no. 1: 7-30. DOI: 10.1177/0033688217690059

Richards, J. C. 2015. Key Issues in Language Teaching. Cambridge: Cambridge University Press.

Richards, K. 2003. Qualitative Inquiry in TESOL. Basingstoke: Palgrave Macmillan.

Roberts, J. 1998. Language Teacher Education. London: Arnold.

Saldaña, J. 2016. The Coding Manual for Qualitative Researchers. London/Thousand Oaks, CA: Sage.

Schön, D. 1983. The Reflective Practitioner. How Professionals Think in Action. London: Temple Smith.

Shulman, L. 1987. Knowledge and Teaching: Foundations of the New Reform. Harvard Educational Review 57, no. 1: 1-22.

Silverman, D. 2010. Doing Qualitative Research ( $3^{\text {rd }}$ ed). London: Sage.

Swain, M., P. Kinnear and L. Steinman. 2015. Sociocultural theory in second language education: an introduction through narratives, 2nd ed., Bristol: Multilingual Matters.

Ulvik, M. and H. Riese. 2016. Action research in pre-service teacher education - a never-ending story promoting professional development. Professional Development in Education 42, no. 3: 441-

57. DOI: $10.1080 / 19415257.2014 .1003089$ 
PRE-PUB VERSION

Villacañas de Castro, L. S. 2015. 'Why should I study English if I'm never going to leave this town?' Developing alternative orientations to culture in the EFL classroom through CAR. Review of Education, Pedagogy, and Cultural Studies 37, no. 4: 289-307. DOI: DOI:

$10.1080 / 10714413.2015 .1065616$

Villacañas de Castro, L. S. 2016. 'We are more than EFL teachers - we are educators': emancipating EFL student-teachers through photovoice. Educational Action Research, DOI: $10.1080 / 09650792.2016 .1215930$

Whong, M. 2013. A linguistic perspective on communicative language teaching. The Language Learning Journal 41, no. 1: 115-28.

Yang, W. 2016. An investigation of learning efficacy, management difficulties and improvements in tertiary CLIL (Content and Language Integrated Learning) programmes in Taiwan: a survey of stakeholder perspectives. Latin American Journal of Content and Language Integrated Learning 9, no. 1: 64-109.

Yule, G. 2017. The study of Language ( $6^{\text {th }}$ ed). Cambridge: Cambridge University Press. 